Terbit online pada laman web jurnal : http://e-journal.sastra-unes.com/index.php/JIPS

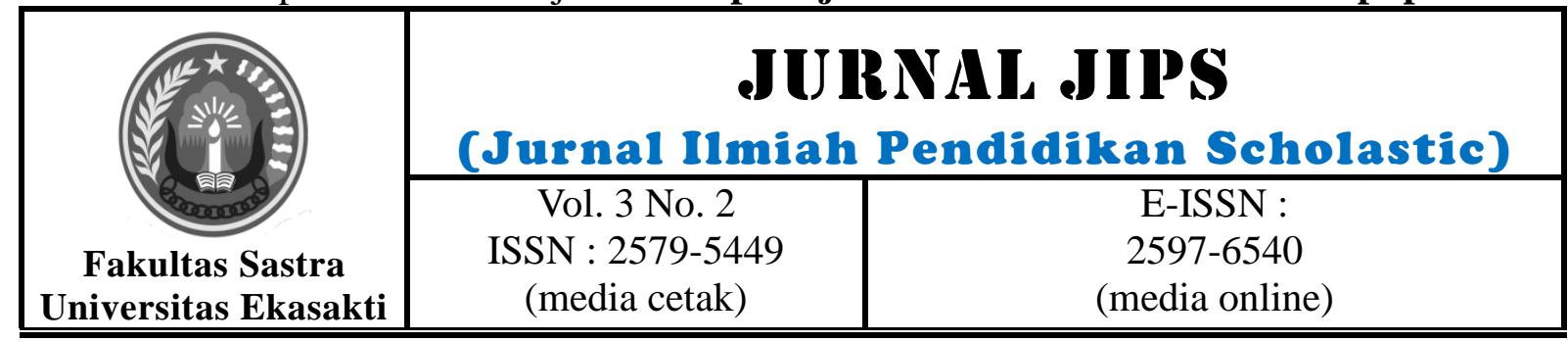

\title{
MANAJEMEN KONFLIK : SUATU PELUANG DALAM MENINGKATKAN PRODUKTIVITAS DALAM ORGANISASI PUBLIK
}

\author{
Krismena Tovalini \\ Program Studi Administrasi Publik, STIA Adabiah Padang \\ tovalinikrismena@gmail.com
}

\begin{abstract}
Suatu organisasi, perusahaan atau lembaga publik pada umumnya dalarn mencapai tujuan, banyak dipengaruhi oleh adanya kerja sarna yang harmonis diantara para karyawannya, Semakin harrnonis kerja sarna yang dilakukan para karyawan biasanya semakin tinggi tingkat produktivitas yang dicapai. Konflik merupakan realita hidup, mau tidak mau, suka atau tidak suka, cepat atau lambat pada suatu saat dalam menjalani kehidupannya setiap orang pasti akan menghadapinya. Dalam kehidupan sehari-hari, konflik dapat timbul kapan saja dan dimana saja. Konflik juga bisa dialami oleh siapa saja tidak pandang bulu, orang tua, remaja, anak-anak, pria, wanita, orang terpelajar, orang awam, orang miskin, jutawan atau siapapun yang hidup di tengah pergaulan umum pasti akan menghadapi dan mengalami konflik. Manajemen konflik adalah proses penyelesaian atau penanganan konflik dengan pengelolaan untuk menciptakan suatu solusi menguntungkan dengan memanfaatkan konflik sebagai sumber inovasi dan perbaikan. Produktivitas kerja adalah hasil kerja secara keseluruhan mencakup kualitas dan kuantitas yang dicapai dalam melaksanakan tugas sesuai dengan tanggung jawabnya.
\end{abstract}

Keywords: Perilaku Organisasi, Konflik, Produktivitas, Organisasi Publik

(C) 2019Jurnal JIPS

\section{INTRODUCTION}

Organisasi dalam segala macam bentuk dan jenisnya dalam mewujudkan tujuan bersama dengan seluruh elemen yang ada pasti pernah mengalami situasi yang tidak bisa memuaskan keinginan semua orang yang terlibat dalam usaha mencapai tujuan tersebut. Hal ini sangat wajar karena di dalam organisasi terdiri dari berbagai macam latar belakang suku, agama, etnis budaya, sosial, ekonomi, politik, dan bahkan negara yang berda-beda. Organisasi yang pada umumnya memiliki tingkat heteroginitas tinggi, sangat potensial terhadap munculnya konflik baik konflik individu maupun konflik organisasi. Dalam interaksi sosial antar individu atau antar kelompok atau kombinasi keduanya, sebenarnya konflik merupakan hal yang alamiah.Konflik adalah segala macam interaksi pertentangan atau antogonistik antara dua atau lebih pihak. Dengan kata lain konflik merupakan ekspresi pertikaian antara individu dengan individu lain, kelompok dengan kelompok lain pada level yang berbedabeda karena beberapa alasan/penyebab utama, yaitu tujuan yang ingin dicapai, dan alokasi sumber-sumber yang dibagikan. Disamping itu, sikap antagonistis dan kontroversi yang ditunjukkan oleh seseorang dalam situasi dan peristiwa tertentu juga menjadi pemicu munculnya konflik dalam suatu organisasi .

Jurnal JIPS (Jurnal Ilmiah Pendidikan Scholastic) Vol. 3No. 3 (2019) ISSN : 2579-5449

This work is licensed under a Creative Commons Attribution-NonCommercial 4.0 International License. 
Memahami konflik dalam organisasi tidak terlepas dari komponen-komponen sistem yang membentuknya. Manusia merupakan salah satu komponen sistem yang perlu dikaji berkaitan dengan dimensi perilaku organisasi, sistem, perubahan, dan pengembangan organisasi. Perubahan lingkungan dalam sebuah organisasi dapat terjadi dalam berbagai situasi dan kondisi, pada akhir nya menuntut sumber daya manusia dan organisasi itu sendiri untuk dapat menyesuaikan diri terhadap perubahan.

Adanya tuntutan perubahan dari organisasi menjadi penyebab munculnya konflik dalam organisasi, baik konflik individu, kelompok maupun antar kelompok .Konflik biasanya juga timbul sebagai hasil adanya masalah-masalah hubungan pribadi (ketidaksesuaian tujuan atau nilai-nilai pribadi karyawan dengan perilaku yang harus diperankan pada jabatannya, atau perbedaan persepsi) dan struktur organisasi (perebutan sumber daya-sumber daya yang terbatas, pertarungan antar departemen dan sebagainya). Ada hakekatnya konflik merupakan suatu pertarungan menang kalah antara kelompok atau perorangan yang berbeda kepentingannya satu sama lain dalam organisasi. Atau dengan kata lain, konflik adalah segala macam interaksi pertentangan atau antagonistik antara dua atau lebih pihak. Pertentangan kepentingan ini berbeda dalam intensitasnya tergantung pada sarana yang dipakai. Masingmasing ingin membela nilai-nilai yang telah mereka anggap benar, dan memaksa pihak lain untuk mengakui nilai-nilai tersebut baik secara halus maupun keras .

\section{RESEARCH METHOD}

Metode yang digunakan dalam artikel ini dengan melakukan studi literatur dengan menelaah jurnal terkait manajemen konflik. Hasil dari berbagai telaah literatur ini akan digunakan untuk mengidentifikasi manajemen konflik

sehingga bisa berdampak kepada produktivitas kinerja pegawai dalam perilaku organisasi.

\section{RESULTS AND DISCUSSION}

Peletakan dasar awal penulis melihat prespektif penganggapan dari pandangan terhadap konflik itu sendiri yang menimbulkan Pertentangan pendapat oleh Robbins disebut sebagai the Conflict Paradox, yaitu pandangan bahwa di satu sisi konflik dianggap dapat meningkatkan kinerja kelompok, namun di sisi lain kebanyakan kelompok dan organisasi berusaha untuk meminimalisir konflik. Dalam uraian di bawah ini disajikan beberapa Penyebab konflik.

Ada beberapa penyebab munculnya konflik dalam organisasi, yakni:

1. Kepemimpinan

Kepemimpinan dalam sebuah organisasi dapat menimbulkan konflik, terutama dalam hal yang berhubungan dengan kebijakan yang di ambil seorang pemimpin. Kebijakan-kebijakan yang diambil oleh pemimpin tentu telah dipikirkan secara matang sebab dan akibat serta konstribusinya bagi kemajuan organisasi sebelum diterapkan. Pandangan seorang

pemimpin mengenai cara kerja lama tidak efektif bagi kemajuan organisasi bahkan dinilai lamban untuk mencapai tujuan maka cara kerja baru yang dinilai potensial menjadi penting untuk diterapkan. Jadi pemimpin harus bisa mensosialisasikan kepada bawahan sehingga kebijakan-kebijakan yang telah dibuat akan dapat diterima oleh bawahan dan tidak menimbulkan protes dari karyawan yang kurang paham dengan kebijakan tersebut.

2. Konflik pembagian dan pelaksanaan tugas

Persepsi negatif karyawan terhadap pembagian dan proses pelaksanaan tugas ini menjadi dasar munculnya konflik dalam dirinya, dan bisa jadi pada orang lain seprofesi. Rasa cemburu terhadap orang lain menimbulkan sakit hati dan iri terhadap rekan seprofesi yang dilimpahkan tugas sedikit, sedangkan dirinya diberi tugas yang banyak. Muncul ketidakikhlasan dalam bekerja, dan sikap apatis yang menyebabkan tugas yang menjadi tanggung jawabnya tidak dapat diselesaikan

Jurnal JIPS (Jurnal Ilmiah Pendidikan Scholastic) Vol. 3No. 3 (2019) ISSN : 2579-5449 
dengan optimal. Disini juga di perlukan perhatian dari atasan dan dari organisasi sendiri, yang mana dalam pembagian tugas setiap karyawan harus seimbang dan sama rata sehingga tidak ada karyawan yang merasa terbebani oleh tugas yang diberikan oleh organisasi.

\section{Sistem penggajian}

Perbedaan sistem penggajian sering menimbulkan konflik dalam internal organisasi. Ada deskriminasi sistem penggajian antara pekerja laki-laki dan perempuan atas prasangka pekerja perempuan lebih lemah dan kurang produktif dari pekerja laki-laki. Karena perbedaan penggajian tersebut akan menyurutkan semangat kerja dari pekerja perempuan, sehingga pekerjaan dalam organisasi pun kurang berjalan dengan baik.

4. Konflik pencapaian visi, misi, dan tujuan organisasi

Konflik dalam pencapaian visi, misi, dan tujuan organisasi dapat terjadi karena individu memandang dirinya sebagai bagian dari organisasi memiliki rekan seprofesi yang memperoleh perlakuan berbeda darinya. Persepsi untung rugi dalam bekerja menimbulkan konflik dalam bekerjasama dengan orang lain, terlebih lagi bila tidak ada kecocokan dalam sebuah tim. Individu merasa tidak dapat bekerjasama dengan individu lain yang dinilai tidak memiliki kecocokan, atau kemiripan dengannya. Perbedaan pendapat terhadap prioritas kerja menjadi faktor penghalang berkaya, akhirnya memilih untuk tidak melakukan apa-apa, akibatnya organisasi tidak dapat mencapai tujuan

\section{Akibat-akibat Konflik}

Konflik yang muncul dan terjadi dalam suatu organisasi/perusahaan yang disebabkan oleh faktor apapun, memiliki konsekuensi atau akibat bagi seluruh elemen oraganisasi tersebut. Sebagai sebuah sebab, maka konflik juga dapat membawa akibat positif dan negatif.

1. Akibat Positif

a. Organisasi memiliki dinamika dan jalinan yang akrab satu sama lain karena adanya interaksi yang intensif antar sesama anggota organisasi baik yang terlibat langsung dengan konflik maupun yang lain. Konflik antar individu atau antar kelompok yang diselesaikan dengan damai dan adil akan membawa keharmonisan dan kebersamaan yang saling menguatkan.

b. Orang-orang yang pernah berkonflik memahami akan dampak yang diakibatkan oleh konflik yang dilakukan, sehingga pengalaman masa lalu dapat dijadikan sebagai pelajaran berharga dalam bekerja. Jika harus terjadi konflik serupa, maka satu sama lain akan saling berusaha memahami dan menyelaraskan dengan lingkungan di mana berada.

c. Konflik yang muncul akibat ketidakpuasan atas diberlakukannya peraturan tentang upah/gaji dan jenis kesejahteraan lainnya yang sebelumnya ditentang, boleh jadi oleh pihak manajemen pemberlakuannya ditunda atau dibatalkan.

d. Konflik yang timbul tetapi bisa diredam dan dikelola secara baik dapat melahirkan kritikkritik membangun, cerdas, kreatif, dan inovatif demi kebaikan organisasi secara keseluruhan baik jangka pendek maupun jangka panjang.

e. Anggota organisasi yang tidak terlibat secara langsung dalam suatu konflik, dapat mengambil hikmah dan bisa belajar bagaimana menghadapi perbedaan sifat, sikap, dan perilaku orang lain di tempat kerja.

\section{Akibat Negatif}

a. Komunikasi organisasi terhambat

b. Kerjasama yang sudah dan akan terjalin antar individu dalam organisasi menjadi terhalang/terhambat.

c. Aktivitas produksi dan distribusi dalam perusahaan menjadi terganggu, bahkan sangat mungkin dapat mengakibatkan turunnya omset penjualan dalam kurun waktu tertentu.

d. Masing-masing pihak yang berkonflik sangat rentan tersulut adanya situasi atau hal lain yang memancing kedua belah pihak untuk berkonflik lagi.

e. Bekerja dalam situasi yang sedang ada konflik menyebabkan orang yang tidak ikut berkonflikpun ikut merasakan dampaknya seperti situasi kerja yang tidak kondusif, antar pegawai/karyawan muncul saling mencurigai, salah paham, dan penuh intrik yang mengganggu hubungan antar individu.

f. Individu yang sedang berkonflik merasa cemas, stres, apatis, dan frustasi terhadap situasi yang sedang dihadapi. Bekerja dalam situasi dan kondisi psikologis seseorang seperti ini tentunya dapat menyebabkan menurunnya etos kerja yang 
akhirnya merugikan produktivitas organisasi/perusahaan secara luas.

g. Akibat terburuk bagi orang-orang yang sedang berkonflik dalam suatu organisasi adalah stres yang berkepanjangan hingga menarik diri dari pergaulan dan mangkir dari pekerjaan. Akibat akumulasi dari kondisi ini adalah yang bersangkutan berhenti atau diberhentikan dari pekerjaan karena seringnya mangkir dari pekerjaan sehingga dapat merugikan perusahaan.

\section{Manajemen konflik}

Perbedaan - perbedaan tersebut mengakibatkan terjadi konflik. Konflik pada suatu organisasi merupakan hal yang mungkin saja terjadi. Hal ini cukup wajar, mengingat yang menjadi anggota-organisasi adalah para manusia yang satu dan lainnya mempunyai banyak perbedaan-perbedaan. Selain perbedaanperbedaan atas; sifat, tingkah laku, jujur, motivasi, status dan kedudukan kerja, sehingga ada perbedaan kepentingan untuk bisa mernahami tentang Konflik, bagaimana konflik itu dikelola, rnaka dalam hal ini kita perlu membicarakan terlebih dahulu; apa, mengapa terjadi konflik dan bagaimana konflik itu bisa dikelola khususnya organisasi sehingga:

1. Di satu pihak konflik dirangsang dan diperlukan untuk mendinamisir kemajuan organisasi.

2. Di lain pihak : konflik tidak menjelma menjadi penghambat terciptanya kerja sarna diantara para anggota organisasi untuk mencapai tujuan.

3. Justru konflik diharapkan dapat rnemunculkan kreatifitas di dalam organisasi.

a. Perencanaan

Kegiatan perencanaan meliputi kegiatankegiatan identifikasi masalah, klasifikasi masalah, dan analisis masalah.

- Identifikasi masalah tahap awal prosedur implementasi berupa identifikasi masalah yang muncul dengan cara melihat gejalagejala yang mengikutinya.

- Klasifikasi masalah konfik muncul disebabkan berbagai macam persoalan, saling berkompetensi untuk mengalokasikan sumberdaya organisasi yang terbatas atau dikarenakan perbedaan tujuan, nilai, atau persepsi dalam menterjemahkan program - program organisasi.

- Analisis masalah setelah dilakukan pengelompokan masalah/penyebab terjadinya konflik, selanjutnya dilakukan terhadap masalah/ sumber konflik yang muncul. Analisis dilakukan untuk mengetahui apakah termasuk kategori penting dan mendesak untuk disesuaikan atau dapat ditunda dengan memperhatikan kemampuan organisasi.

b. Pelaksanaan

Kegiatan pelaksanaan manajemen konflik meliputi antara lain:

- Penentuan Metode/Pendekatan Penentuan atau pemilihan pendekatan sangat bergantung pada masalah yang muncul, dan kemampuan pimpinan dalam mengelola konflik agar menjadi kekuatan organisasi. Pemilihan pendekatan harus dipertimbangkan sungguh-sungguh kemungkinan dampak yang dapat ditimbulkan diusahakan berpengaruh pada peningkatan kinerja secara individu atau kelompok.

- Penyelesaian masalah melalui manajemen konflik. Pendekatan manajemen konflik merupakan tahapan lanjutan setelah dilakukan analisis masalah. Konflik yang terjadi dapat menggantungkan/ fungsional dan merugikan atau menghambat pencapaian tujuan organisasi. Pendekatan manajemen konflik yang dipilih dan diterapkan bergantung pada masalah yang dihadapi dan dampak yang ditimbulkan.

c. Evaluasi

Keberhasilan manajemen konflik dapat dilihat dari sikap dan perilaku (kinerja) individu atau kelompok karyawan. Dampak positif dapat dicapai apabila anggota organisasi menunujukkan motivasi kerja, berusaha mencari pemecahan masalah setiap terjadi perbedaan atau pertentangan, mengadakan evaluasi selama proses kegiatan dan membandingkan dengan standar yang telah ditetapkan, mengadakan perubahan jika terdapat kesalahan dalam prosedur kerja, dan berorientasi pada tujuan/tugas. 


\section{Produktivitas Kerja}

Sulistiyani dan Rosidah (2009:247) mengungkapkan produktivitas menyangkut hasil akhir, yakni seberapa besar hasil akhir yang diperoleh di dalam proses produksi. Dalam hal ini tidak terlepas dengan efisiensi dan efektifitas. Berikut faktor-faktor yang menentukan besar kecilnya produktivitas suatu instansi. Berikut indikator produktivitas kerja menurut Sulistiyani dan Rosidah (2009:249) adalah sebagai berikut:

1. Knowledge atau Pengetahuan dan keterampilan sesungguhnya yang mendasari pencapaian produktivitas. Ada beberapa substansial antara pengetahuan dan ketrampilan. Konsep pengetahuan lebih berorientasi pada intelejensi, daya pikir dan penguasaan ilmu serta luas sempitnya wawasan yang dimiliki seseorang. Dengan demikian pengetahuan merupakan akumulasi hasil proses pendidikan baik yang diperoleh secara formal maupun non formal yang memberikan kontribusi pada seseorang didalam pemecahan masalah, daya cipta, termasuk dalam melakukan atau menyelesaikan pekerjaan. Dengan pengetahuan yang luas dan pendidikan tinggi, seorang pegawai diharapkan mampu melakukan pekerjaan dengan baik dan produktif.

2. Skill atau Keterampilan adalah kemampuan dan penguasaan teknis operasional mengenai bidang tertentu, yang bersifat kekaryaan. Keterampilan diperoleh melalui proses belajar dan berlatih. Keterampilan berkaitan dengan kemampuan seseorang untuk melakukan atau menyelesaikan pegawai-pegawai yang bersifat teknis, seperti keterampilan komputer, keterampilan bengkel, dan lainlain. Dengan keterampilan yang dimiliki seorang pegawai dharapkan mampu menyelesaikan pekerjaan secara produktif. Keterampilan merupakan variabel yang bersifat utama dalam membentuk produktivitas. Dengan kata lain jika seorang pegawai memiliki keterampilan yang baik maka akan semakin produktif.

3. Abilities atau kemampuan terbentuk dari sejumlah kompetensi yang dimiliki oleh seorang pegawai. Konsep ini jauh lebih luas, karena dapat mencakup sejumlah kompetensi. Pengetahuan dan keterampilan termasuk faktor pembentuk kemampuan. Dengan demikian apabila seseorang mempunyai pengetahuan dan keterampilan yang tinggi, diharapkan memiliki ability yang tinggi pula. Melalui kemampuan yang memadai, maka seseorang dapat melaksanakan aktivitas dengan tanpa ada permasalahan teknis.

4. Sangat erat hubungan antara kebiasaan dan perilaku. Attitude merupakan suatu kebiasan yang terpolakan. Jika kebiasaan yang terpolakan tersebut memiliki implikasi positif dalam hubungannya perilaku kerja seseorang maka akan menguntungkan. Arti yang dimaksudkan diatas, apabila kebiasaan-kebiasaan pegawai adalah baik, maka hal tersebut dapat menjamin perilaku kerja yang baik pula. Dapat dicontohkan disini misalnya seorang pegawai mempunyai kebiasaan tepat waktu, disiplin, simpel, maka perilaku kerja juga baik, apabila diberi tanggungjawab akan menepati aturan dan kesepakatan.

5. Dengan demikian perilaku manusia atau behaviors juga ditentukan oleh kebiasaankebiasaan yang telah tertanam dalam diri pegawai sehingga dapat mendukung kerja yang efektif atau sebaliknya. Dengan kondisi pegawai tersebut, maka produktivitas dapat dipastikan dapat terwujud.

\section{Pengaruh Konflik terhadap Produktivitas Kerja}

Hasil penelitian pada studi literatur yang penulis dapatkan menunjukan bahwa konflik kerja berpengaruh dan signifikan terhadap produktivitas kerja. Ini sejalan dengan asumsi dalam hipotesa. Dengan kata lain H3 (hipotesa ketiga) diterima: semakin meningkat tingkat konflik maka semakin menurun produktivitas kerja. Hasil ini berbeda dengan yang ditemukan oleh Utami (2013) yang menemukan bahwa konflik memberikan sumbangan efektif terhadap produktivitas kerja. Hasil penelitian di Unika De La Salle menunjukkan bahwa konflik berdampak penurunan produktivitias kerja. Hasil ini memperkuat penegasan dari Rivai dan Sagala (2013:999) bahwasannya konflik mengancam kelangsungan perusahaan untuk meningkatkan 
produktivitas kerja. Produktivitas kerja terkait dengan besarnya hasil akhir yang dicapai oleh perusahaan dalam keseluruhan proses produksi (Sulistiyani dan Rosidah 2009:249).

Akan tetapi hasil akhir ini hanya dimungkinkan apabila terdapat efisiensi dan efektivitas selama proses produksi, yang mana salah satu unsur di antaranya yakni proses kerja. Dalam situasi lingkungan kerja Unika De La Salle, konflik kerja tidak mendukung kerja yang efektif. Ditambahkan di sini catatan tentang indikator produktivitas kerja sebagaimana ditegaskan oleh Sulistiyani dan Rosidah. Unsur yang dianggap menjadi dasar pencapaian produktivitas kerja, yakni: pengetahuan (knowledge), keterampilan (skill), kemampuan (abilities), perilaku (attitude) dan kebiasaan (behaviors). Dalam konteks lingkungan Unika De La Salle, unsur- unsur tersebut masih perlu dilengkapi dengan aspekaspek lainnya: lingkungan kerja (environement), yakni kondisi-kondisi kesekitaran lingkungan kerja, termasuk di dalamnya sistem, relasi, komunikasi, interaksi baik antara pimpinan dan karyawan, antara karyawan maupun antara pekerjaan dan sarana-sarana pendukung kerja.

\section{Hubungan Konflik Dan Prestasi}

Hubungan antara konflik organisasi dan prestasi nampak pada garnbar sebagai berikut:

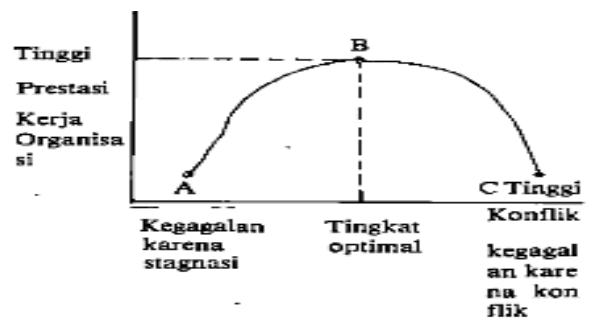

Gambar No. 1 Hubungan antara Prestasi dan konflik
Jadi titik A : prestasi dan konflik sangat rendah, hingga terjadi stagnasi. Hal ini karena konflik hampir tidak pemah terjadi (situasi manajemen dan terfokus pada kegiatan rutin). Sementara pada titik C: konflik terlampau tinggi, Pihak manajer sulit mengatasinya dan terjadi kekacauan yang berlebihan, sehingga prestasi am at rendah (nol).

Dalam gambar tersebut terdapat tingkat konflik fungsional yang tinggi dan optimal. Pada titik ini prestasi organisasi berbeda pada tingkat rnaksimal (pada titik B).

Dari gambar hubungan tersebut dapat disimpulkan bahwa jika konflik dalam organisasi relatif rendah bahkan tidak ada konflik maka prestasi kemajuan organisasi juga relatif rendah.

Sebaliknya jika konflik yang terjadi di dalam organisasi terlalu tinggi bahkan mencapai pada taraf antago- nistis antara pihak yang satu dengan yang lain dalam organisasi itu maka dapat berakibat organisasi mengalami kemunduran,dengan kata lain prestasi kerjanya rendah.

Oleh karena itu yang diinginkan adalah konflik tetap diperlukan dalam batas-batas tertentu yang hanya terbatas pada konflik positif dan konstruktif. Karena dengan konflik positif dan konstruktif yang sedang-sedang saja justru akan dapat memperoleh prestasi kerja secara keseluruhan pada tingkat yang optimal. 


\section{CONCLUSION}

Konflik dapat berdampak positif dan negatif yang rinciannya adalah sebagai berikut :

a. Dampak Positif Konflik

1. Meningkatnya ketertiban dan kedisiplinan dalam menggunakan waktu bekerja, seperti hampir tidak pernah ada karyawan yang absen tanpa alasan yang jelas, masuk dan pulang kerja tepat pada waktunya, pada waktu jam kerja setiap karyawan menggunakan waktu secara efektif, hasil kerja meningkat baik kuantitas maupun kualitasnya.

2. Meningkatnya hubungan kerjasama yang produktif. Hal ini terlihat dari cara pembagian tugas dan tanggung jawab sesuai dengan analisis pekerjaan masingmasing.

3. Meningkatnya motivasi kerja untuk melakukan kompetisi secara sehat antar pribadi maupun antar kelompok dalam organisasi, seperti terlihat dalam upaya peningkatan prestasi kerja, tanggung jawab, dedikasi, loyalitas, kejujuran, inisiatif dan kreativitas.

4. Semakin berkurangnya tekanan-tekanan, intrik-intrik yang dapat membuat stress bahkan produktivitas kerja semakin meningkat. Hal ini karena karyawan memperoleh perasaan-perasaan aman, kepercayaan diri, penghargaan dalam keberhasilan kerjanya atau bahkan bisa mengembangkan karier dan potensi dirinya secara optimal.

5. Banyaknya karyawan yang dapat mengembangkan kariernya sesuai dengan potensinya melalui pelayanan pendidikan (education), pelatihan (training) dan konseling (conselling) dalam aspek kognitif, afektif dan psikomotorik. Semua ini bisa menjadikan tujuan organisasi tercapai dan produktivitas kerja meningkat akhirnya kesejahteraan karyawan terjamin.

b. Dampak Negatif

1. Meningkatkan jumlah absensi karyawan dan seringnya karyawan mangkir pada waktu jam-jam kerja berlangsung seperti misalnya ngobrol berjam-jam sambil mendengarkan sandiwara radio, berjalan mondar-mandir menyibukkan diri, tidur selama pimpinan tidak ada di tempat, pulang lebih awal atau datang terlambat dengan berbagai alasan yang tak jelas.

2. Banyak karyawan yang mengeluh karena sikap atau perilaku teman kerjanya yang dirasakan kurang adil dalam membagi tugas dan tanggung jawab. Seringnya terjadi perselisihan antar karyawan yang bisa memancing kemarahan, ketersinggungan yang akhirnya dapat mempengaruhi pekerjaan, kondisi psikis dan keluarganya.

3. Banyak karyawan yang sakit-sakitan, sulit untuk konsentrasi dalam pekerjaannya, muncul perasaan-perasaan kurang aman, merasa tertolak oleh teman ataupun atasan, merasa tidak dihargai hasil pekerjaannya, timbul stres yang berkepanjangan yang bisa berakibat sakit tekanan darah tinggi, maag ataupun yang lainnya.

4. Seringnya karyawan melakukan mekanisme pertahanan diri bila memperoleh teguran dari atasan, misalnya mengadakan sabotase terhadap jalannya produksi, dengan cara merusak mesin-mesin atau peralatan kerja, mengadakan provokasi terhadap rekan kerja, membuat intrik-intrik yang merugikan orang lain.

5. Meningkatnya kecenderungan karyawan yang keluar masuk dan ini disebut labor turnover. Kondisi semacam ini bisa menghambat kelancaran dan kestabilan organisasi secara menyeluruh karena produksi bisa macet, kehilangan karyawan potensial, waktu tersita hanya untuk kegiatan seleksi dan memberikan latihan dan dapat muncul pemborosan dalam cost benefit.

Menurut Stevenin dalam jurnal ( Jefri Herdinianyah. 2014) terdapat lima langkah dalam meredakan konflik:

1. Pengenalan kesenjangan antara keadaan yang ada diidentifikasi dan bagaimana keadaan yang seharusnya

2. Diagnosis, menguji mengenai siapa, apa, mengapa, dimana, dan bagaimana berhasil dengan sempurna. Memperhatikan masalah utama yang terjadi 
3. Menyepakati suatu solusi, mengumpulkan masukan untuk mencari solusi atau jalan keluar dan menyaring penyelesaian yang tidak dapat diterapkan atau tidak praktis

4. Pelaksanaan, dengan konsekuensi adanya keuntungan dan kerugian

5. Evaluasi, jika penyelesaiannya tampak tidak berhasil, kembalilah ke langkahlangkah sebelumnya dan cobalah lagi.

Menurut ( Zalaback, 2006 : 325-326) ada 4 cara untuk mengurangi adanya konflik diantaranya adalah mengidentifikasi kemungkinan sejumlah isu dan fokus pada pendekatan mengenai isu yang dihadapai, menjabarkan perilaku dan dampak untuk dihindari selama konflik berlangsung, menunjukkan kepedulian terhadap data yang diperoleh dan perasaan dari karyawan, menawarkan bentuk kompromi jabatan atau posisi yang tetap.

Dari beberapa pendapat diatas, penulis hanya menemukan beberapa cara penyelesaian konflik yang diterapkan di perusahaan PT. Sumi Rubber khusunya dalam internal departemen Purchasing diantaranya adalah:
1. Mencari sebab terjadinya konflik, metode yang digunakan adalah dengan menjabarkan akar permasalahan dengan diagram "fishbone". Manfaat fishbone diagram ini dapat menolong kita untuk menemukan akar penyebab masalah secara user friendly, tools yang user friendly disukai orang-orang di industri manufaktur di mana proses di sana terkenal memiliki banyak ragam variabel yang berpotensi menyebabkan munculnya permasalahan.

2. Mengumpulkan data secara empiris yang didapat dari penelusuran masalah baik data secara tertulis maupun hasil narasumber.

3. Mempertemukan pihak pihak yang melakukan konflik dengan mencocokkan data atau informasi yang didapat untuk memecahkan masalah yang terjadi

4. Mencari solusi secara bersama sama dengan berdialog terhadap masalah yang terjadi.

Melakukan tindakan pencegahan konflik jika terjadi kejadian yang sama dikemudian hari dengan mendata kejadian tersebut sehingga tidak terjadi kembali. 


\section{Bibliography}

[1]Alo, L. (2018). Prasangka, Konflik, dan Komunikasi antarbudaya. Jakarta: KENCANA.

[2]Anwar, C. (2015, July 2). Manajemen Konflik Untuk Menciptakan Komunikasi Yang Efektif (Studi Kasus Di Departemen Purchasing PT. Sumi Rubber Indonesia). JURNAL INTERAKSI, Vol 4, 148 - 157.

[3]R.H. Lucia., L. K. (2015, September 3). Pengaruh Konflik Dan Stres Kerja Terhadap Produktivitas Kerja Dimediasi Oleh Kepuasan Kerja Karyawan Universitas Katolik De La Salle Manado. Jurnal EMBA (ISSN 2303-11 ), 719-728.
[4]Sunarta. (2011). Konflik Dalam Organisasi (merugikan sekaligus menguntungkan). Jurnal Administrasi, 1-3.

[5]Tumengkol, S. M. (2016). Dinamika Konflik Dalam Organisasi . Jurnal LPPM Bidang EkoSosBudKum , 47-49.

[6]Weni, P. (2018). Manajemen Konflik (Suatu Pendekatan Psikologi, Komunikasi, Dan Pendidikan). Yogyakarta: CV BUDI UTAMA.

[7]Wijayanti., D. T. (2009). Modal Konseptual Manajemen Konflik Dalam Organisasi. Jurnal Bisnis dan Manajemen, 7-9. 